ISSN 1392-3196 / e-ISSN 2335-8947

Zemdirbyste-Agriculture, vol. 105, No. 3 (2018), p. 211-220

DOI 10.13080/z-a.2018.105.027

\title{
Evaluation of contamination levels of different types of composts and their suitability for usage in agriculture
}

\author{
Indrè VIŠNIAUSKE ${ }^{1}$, Karolina BARČAUSKAITE ${ }^{2}$, Eugenija BAKŠIENË ${ }^{3}$, Romas MAŽEIKA² \\ ${ }^{1}$ Agrochemical Research Laboratory, Lithuanian Research Centre for Agriculture and Forestry \\ Savanorių 287, Kaunas, Lithuania \\ E-mail: indre.visniauske@gmail.com \\ ${ }^{2}$ Institute of Agriculture, Lithuanian Research Centre for Agriculture and Forestry \\ Instituto al. 1, Akademija, Kèdainiai distr., Lithuania \\ ${ }^{3}$ Vokè Branch, Lithuanian Research Centre for Agriculture and Forestry \\ Žalioji a. 2, Vilnius, Lithuania
}

\begin{abstract}
The aim of the study was to investigate the composition of different organic substances and the amount of nutrients in composts produced from green waste, food waste, sewage sludge, cattle manure and digestate as well as to assess the contamination with persistent organic pollutants and heavy metals. Composts produced in 2015 and 2016 in different regions of Lithuania and in different weather conditions were used for the research. Chemical analyses of composts were done according to the international standards and requirements for soil improvement substances. Of all the composts tested, green waste compost had the lowest content of organic matter, nitrogen and phosphorus. The results of the experiment suggest that digestate, which was characterised by the highest organic matter content, contained the smallest quantity of fulvic and humic acids that are of key importance to the recovery of soil organic content. It was established that sewage sludge composts were the most contaminated with heavy metals and polychlorbiphenyls; the content of the analysed polychlorbiphenyls totalled $37.8 \mu \mathrm{g} \mathrm{kg}^{-1}$ in the samples of the year 2015 and $29.4 \mu \mathrm{g} \mathrm{kg}^{-1}$ in the samples of 2016 . The lowest content of heavy metals and polychlorbiphenyls was recorded in cattle manure and food waste composts. No polychlorbiphenyls were found in the samples of 2015. The findings suggest that sewage sludge compost is the least suitable for being used in agriculture, because of its pollution with heavy metals and persistent organic pollutants. Green waste compost only increased the quantity of organic matter, while compost from cattle manure, food waste and digestate not only improved the soil structure, but significantly increased nutrients concentration.
\end{abstract}

Key words: fulvic acid, humic acid, organic matter, polychlorbiphenyls, polycyclic aromatic hydrocarbons.

\section{Introduction}

Given the soil organic matter losses, the recycling of large amounts of organic wastes generated by human activities appears to present a significant potential source of soil amendment (Watteau, Villemin, 2011). Large quantities of various wastes accumulate in the world annually. Due to mismanagement of wastes, the threat of infection is posed to humans and animals, therefore, waste separation and sorting, processing and recycling of certain materials or waste recovery are carried out in the outlying areas of their sources. Composting is biological degradation of organic compounds in waste under aerobic (Schuchardt, 2005) or anaerobic conditions (Butkovskyi et al., 2016). During composting the content of phytotoxic substances, as well as greenhouse gas emissions, is reduced (Schuchardt, 2005). Biodegradable wastes include garden waste, contaminated or improperly recycled paper and paperboard, liquid and solid wastes arising in the manufacture of food products and during food selling (Montanarella, Rusco, 2002; Said-Pullicino, Gigliotti, 2007; Fialho et al., 2010; Eshetu et al., 2012). In Lithuania, different types of composts are produced, namely those from the wastes of plant origin, food waste, sewage sludge, manure, digestate, biodegradable municipal waste and vermicomposts. In Germany, Norway and Switzerland composting of organic waste is very important and is well known as a green and costeffective way of recycling. The amounts of organic waste are increasing every year and its annual production accounts for approximately $9.3 \times 10^{6} \mathrm{t}$ of compost and digestate in the 25 countries of the European Union (Kupper et al., 2008; Singh, Kalamdhad, 2013). Composts are produced from tree leaves, branches, sewage sludge, food waste, manure, straw, etc. The highest-value composts are obtained by mixing tree bark, branches or animal waste with the materials with high carbon content or straw (Hoitink et al., 2008).

Please use the following format when citing the article: 
Compost is an essential organic fertiliser for recovering organic matter in degraded soils. The higher the amount of organic matter in soil the better soil physical and chemical properties-soil basicity, structure, airpermeability, thermal conductivity and water permeability; nutrients are better assimilated as well as soil fertility is maintained and the production volume is increased (Sánchez-García et al., 2015). Staugaitis et al. (2016) indicated that when winter wheat was grown, green waste, sewage sludge, cattle manure and digestate composts did not have statistically significant effect on crop yield. The same experiment was done with spring barley. The obtained results showed that application of compost increased crop yield (Bedada et al., 2014 crop productivity and soil organic matter buildup were compared in soils receiving locally made compost, applied either alone or in combination with NP fertilizer. The experiments had four treatments: full dose of compost (C; Staugaitis et al., 2016).

Composts are not only rich in nutrients, microand macroelements beneficial for soil and plants, but they also contain heavy metals and persistent organic pollutants. Compost contamination depends on the quality of composted material as well as on a composting technology (Riedel, Marb, 2008; Staugaitis et al., 2016). It is very important both to assess a fertiliser value and the contamination of composts. Scientific studies have established that the highest contamination is related to the composts produced from sewage sludge (Harrison et al., 2006; Kupper et al., 2008). The least toxic are composts produced from plant residues; however, their fertiliser value is not high (Paradelo et al., 2008).

This study investigated the contents of polychlorbiphenyls and polycyclic aromatic hydrocarbons in the composts of different origin. Polycyclic aromatic hydrocarbon immobilization in compost organic matter determines its qualitative and quantitative properties (Guo et al., 2010; Debska et al., 2011; Banach-Szott et al., 2014). Humin can sorb greater quantities of polycyclic aromatic hydrocarbons; however, complexes with humic acids form faster. There is scientific evidence of a direct link between polychlorbiphenyls content and humic acid concentrations (Tremolada etal., 2012). It has been proved that humic acids have a higher sorption capacity towards persistent organic pollutants than fulvic acids (Pettit, 2004; Banach-Szott et al., 2014). The present knowledge regarding organic pollutant quantities in composts produced in Lithuania and in the world is insufficient. This scientific work of ecological importance will facilitate the assessment of the quality of composts produced in Lithuania. This study is the first attempt to investigate persistent organic pollutants in composts produced in Lithuania. Also, this article provides information about organic substances, quantities of nutrients and heavy metals in five different origin composts. This article also provides information on five different sources of organic material, nutrients and heavy metals, and how these different amounts are used in the use of different raw materials for compost production.

The aim of the study was to investigate the composition of different organic substances and the content of nutrients in the composts produced from green waste, food waste, sewage sludge, cattle manure and digestate as well as to assess their contamination with persistent organic pollutants and heavy metals.

\section{Materials and methods}

Compost sampling. Five types of compost were used in the experiments: 1) green waste compost (GWC) - tree leaves, cut grass, branches, straw and leaves of different vegetables as well as the waste of their processing; the compost was sieved through a $14 \mathrm{~mm}$ sieve (moisture content $-41.2 \pm 0.52 \%$ ); 2 ) food waste compost (FWC) - expired food products: vegetables, fruit, dairy products, heat treated meat and waste from catering enterprises (moisture content $-46.4 \pm 6.3 \%$ ); 3 ) sewage sludge compost (SSC) - sewage sludge was mixed with peat, branches or straw at a ratio of $1: 2$ (moisture content $-52.7 \pm 2.9 \%$ ); 4) manure compost (MC) - produced from cattle manure and mixed with straw, peat and dirt (moisture content $-60.5 \pm 4.50 \%$ ); 5) digestate (DIG) - produced during anaerobic digestion used for processing cereals into bioethanol (moisture content $-72.7 \pm 2.70 \%$ ). The composts were taken from regional waste management centres of Lithuania: Alytus (green waste compost), Kaunas (manure compost), Rokiškis (food waste compost), Pasvalys (digestate) and Vilnius (sewage sludge compost) districts. The composts differed in their origin and manufacturing technology. The physical properties of compost samples varied in colour, density and structure. Each compost sample was taken from 4-6 spots at equal distance of the heap to make composite sample. The places were chosen where the composts were homogeneous, friable, loose and dark-coloured; it was completely decomposed raw material. Approximately $1 \mathrm{~kg}$ of sample was taken from the shovel 60-90 cm deep in a plastic bag and stored in crates at approximately $1-5^{\circ} \mathrm{C}$. Compost samples were dried at a temperature of $75 \pm 5^{\circ} \mathrm{C}$; for fulvic (HA) and humic (FA) acids and polychlorinated biphenyls (PCBs), polycyclic aromatic hydrocarbons (PAHs) analysis composts were air-dried at $40^{\circ} \mathrm{C}$. The composts dried until the loss in mass of compost sample was not larger than $5 \%$ per $24 \mathrm{~h}$. The dried compost samples were milled to particle size $<2 \mathrm{~mm}$. Then the samples were sieved through a $2 \mathrm{~mm}$ sieve.

This article presents chemical composition of composts produced in 2015 and 2016. The composting process of the first year continued from September 2014 until March 2015. The composting process of the second year continued from September 2015 to March 2016 (Fig. 1).

Chemical analyses. All chemical parameters of composts were determined in the Agrochemical Research Laboratory of the Lithuanian Research Centre for Agriculture and Forestry. Organic matter in the composts was determined by a gravimetric method according to the standard EN 13039:2012 (Soil improvers and growing media - Determination of organic content and ash), total nitrogen $(\mathrm{N})$ was determined by the Kjeldahl nitrogen distiller in accordance with the standard EN 13654-1:2012 (Soil improvers and growing media Determination of nitrogen. Modified Kjeldahl method), total phosphorus (P) and sulphur (S) were determined in aqua regia by spectrometric method according to EN 13650:2001 (Soil improvers and growing media - Extraction of aqua regia soluble elements) and EN ISO 11885:2009 (Water quality - Determination of selected elements by inductively coupled plasma optical emission spectrometry (ICP-OES)) using an atomicemission spectrometer Optima 2100 DV (Perkin Elmer, USA). Organic carbon $\left(\mathrm{C}_{\mathrm{org}}\right)$ was determined by a dry 


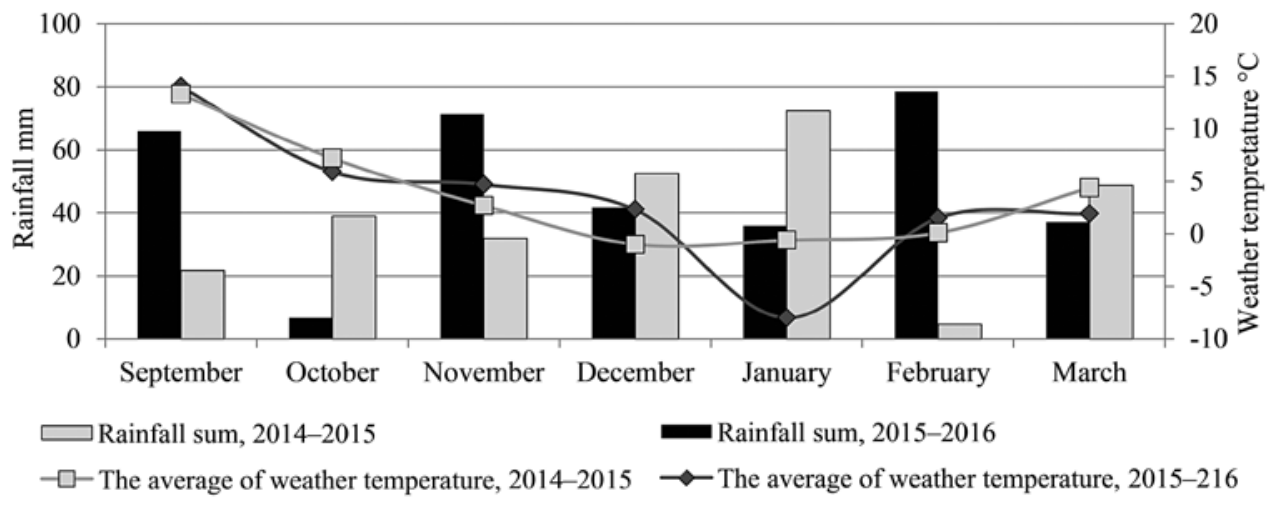

Figure 1. Weather conditions during composting period

combustion method using a total carbon analyser Liqui TOC II (Elementar, Germany). Water soluble ammonia nitrogen and $\mathrm{P}$ were determined by an ion chromatograph Shimadzu Prominence (Shimadzu, Japan) according to the standard EN 13652:2004 (Soil improvers and growing media - Extraction of water soluble nutrients and elements). Water soluble and total potassium (K) were determined according to EN 13650:2006 (Soil improvers and growing media - Extraction of aqua regia soluble elements) and ISO 9964-3:1998 (Water quality - Determination of sodium and potassium Part 3: Determination of sodium and potassium by flame emission spectrometry) using flame emission photometer PFP7 (Jenway, UK). Heavy metals in composts were determined in by the standards ISO 11466:2016 (Soil quality - Extraction of trace elements soluble in aqua regia) and ISO 11047:2015 (Soil quality - Determination of cadmium, chromium, cobalt, copper, lead, manganese, nickel and zinc - Flame and electro thermal atomic absorption spectrometric methods) using the atomicemission spectrometer Optima 2100 DV (Perkin Elmer).

Fulvic and humic acids (FA and $H A$ ) analysis. Ten grams of each compost sample air-dry sieved $(\leq 2 \mathrm{~mm})$ was weighed into a $250 \mathrm{ml}$ plastic centrifuge bottle supplemented with $200 \mathrm{ml} 0.5 \mathrm{M} \mathrm{NaOH}$ and shaken overnight (Faithfull, 2002). Then the sample was centrifuged at $2000 \times \mathrm{rpm}$ for $20 \mathrm{~min}$ to allow sedimentation of the insoluble humin and all the supernatant was decanted into a clean centrifuge bottle. The solution was adjusted to $\mathrm{pH} 2.0$ with $6 \mathrm{M} \mathrm{HCl}$, then centrifuged at $2000 \times \mathrm{rpm}$ for $20 \mathrm{~min}$ to cause sedimentation of the HA. The solution of FA was decanted into a $250 \mathrm{ml}$ volumetric flask. Then the sediment of HA was washed with $30 \mathrm{ml} 0.5 \mathrm{M} \mathrm{HCl}$, centrifuged, supernatant was added to the volumetric flask, and made up to the mark with water and mixed. The optical density was read at $465 \mathrm{~nm}$, diluted if necessary to bring on scale. The HA residue was washed with $200 \mathrm{ml} 0.5 \mathrm{M} \mathrm{HCl}$, centrifuged and supernatant discarded. The HA was washed out of the centrifuge bottle into a pre-weighed oven-dry $100 \mathrm{ml}$ glass beaker. The sample was carefully evaporated to dryness on a hotplate, avoiding loss by spiting, cooled in desiccator and reweighted. The difference in weights gave the weight of HA plus ash. The sample was combusted in a muffle furnace at $500^{\circ} \mathrm{C}$ overnight to burn off HA fraction, cooled in a desiccator, and then the beaker containing the residual ash was reweighed.

Polychlorinated biphenyls (PCBs) analysis and gas chromatography-electron capture detector (GC-
ECD) analysis conditions. Ten grams of an air-dried compost sample was weighted. Fifty $\mathrm{ml}$ of acetone was added to the sample. The flask with the sample and solvent for 20 mins was placed in an ultrasonic bath (Bandelin Sonorex, Germany). During the experiment, $35 \mathrm{kHz}$ ultrasonic energy was used. After $20 \mathrm{~min}, 50 \mathrm{ml}$ of petroleum ether was added and treated with the ultrasound for $20 \mathrm{~min}$ again. Then the solvents were decanted into a separatory funnel, $400 \mathrm{ml}$ of bi-distilled water was added to remove acetone. Additional $50 \mathrm{ml}$ of petroleum ether was added to the flask and treated with ultrasound for 20 minutes. Petroleum ether extract was cleaned up on alumina columns. The cleaned up petroleum ether was evaporated using a rotary evaporator (IKA, Germany) and diluted with hexane to required concentration. The extract obtained was analysed by a gas chromatograph coupled with an electron capture detector (Shimadzu, Japan). Auto-injector AOC-20i (Shimadzu, Japan) was used. One microliter sample volume was injected by the auto-injector in a split mode at the ratio 1:5. PCB separation was performed using a capillary column Rtx1HT (Restek, USA) of 30 metres in length. Column thickness was $0.25 \mu \mathrm{m}$, inner diameter $-0.32 \mathrm{~mm}$. The PCB content in composts was determined by the external standard method in accordance with peak retention time. The concentration was calculated by a calibration curve in the range of 0.01 to $0.1 \mu \mathrm{g} \mathrm{ml}^{-1}$. Injector temperature was set at $280^{\circ} \mathrm{C}$. Carrier gas was helium, flow rate $1.63 \mathrm{ml} \mathrm{min}^{-1}$. Detector temperature was set to $320^{\circ} \mathrm{C}$. The column temperature gradient was programmed as follows: initial temperature $80^{\circ} \mathrm{C}$, then increased to $120^{\circ} \mathrm{C}$ at a rate of $10^{\circ} \mathrm{C} \mathrm{min}^{-1}$, then increased to $220^{\circ} \mathrm{C}$ at a rate of $0.8^{\circ} \mathrm{C} \mathrm{min}^{-1}$, and then again up to $250^{\circ} \mathrm{C}$ at $10^{\circ} \mathrm{C}$ $\min ^{-1}$ and was maintained for 5 minutes.

Polycyclic aromatic hydrocarbons (PAHs) analysis. About $10 \mathrm{~g}$ of an air-dried compost sample was weighed. Fifty $\mathrm{ml}$ of acetone and $50 \mathrm{ml}$ of petroleum ether was added to the sample. The flask with the sample and solvents for 12 hours was placed in a rotary shaker (Biosan PSU20i, Latvia) at $120 \times \mathrm{rpm}$. After 12 hours, the solvents were decanted into a separatory funnel; $400 \mathrm{ml}$ of bi-distilled water was added to remove acetone. The layer of petroleum ether was collected into a beaker. Additional $50 \mathrm{ml}$ of petroleum ether were added to the flask with the sample and treated with ultrasound for 15 minutes. Petroleum ether extract was cleaned up on alumina columns. The cleaned up petroleum ether was evaporated to obtain dry residue using a rotary evaporator (IKA, Germany), and $1 \mathrm{ml}$ of acetonitrile was added. The extract 
was filtered through a $0.45 \mu \mathrm{m}$ pore size membrane filter and analysed by the liquid chromatography method. The work conditions for chromatographic analysis: mobile phase flow rate $0.7 \mathrm{ml} \mathrm{min}{ }^{-1}$, injection volume of $10 \mu 1$, column temperature $30^{\circ} \mathrm{C}$; a diode array detector used for the detection of polycyclic aromatic hydrocarbons, wavelength $254 \mathrm{~nm}$. The mobile phase was supplied to the column with binary gradient $(50 \% \mathrm{~A}$ and $50 \% \mathrm{~B})$. Mobile phase components used for gradient elution: A methanol-water $(80: 20 \mathrm{v} / \mathrm{v}), \mathrm{B}$ - acetonitrile. The content of polycyclic aromatic hydrocarbons was determined by the external standard method in accordance with peak retention time. The Shimadzu chromatography system (Shimadzu Corporation, Japan) was used. YMC PAH column was used for polycyclic aromatic hydrocarbon separation with a $5 \mu \mathrm{m}$ particle pre-column; column length of $250 \mathrm{~mm}$, and internal diameter of $4.6 \mathrm{~mm}$.

Statistical analysis. As treatments were performed in triplicate, all values were reported as the mean values of three samples \pm standard deviation. Statistical significance of the nutrient content data was assessed using Duncan's test; significant differences were established between the data lettered $a, b, c, d, e, f$, $\mathrm{g}$ and $\mathrm{h}$ at $5 \%$ probability level $(p \leq 0.05)$.

\section{Results and discussion}

By their origin, composts were very different not only in their appearance, processed materials and physical properties but also in the organic matter composition and the content of nutrients as well as heavy metal levels. The results of the organic matter composition in different types of composts were presented in Table 1. Organic matter is the soil quality indicator as it provides the soil with energy and nutrients; it improves soil structure, crumbliness, porosity, moisture permeability, and it maintains the balance between soil and the plant. Organic carbon $\left(\mathrm{C}_{\text {org }}\right)$ is an important component of soil organic matter (Scaglia et al., 2015).

Table 1. Organic substances in different types of compost (results expressed in \% of dry matter)

\begin{tabular}{|c|c|c|c|c|c|}
\hline \multirow[b]{2}{*}{ Composts } & \multirow[b]{2}{*}{ Year } & \multicolumn{4}{|c|}{ Content of organic matter components } \\
\hline & & $\begin{array}{l}\text { organic } \\
\text { matter }\end{array}$ & $\begin{array}{c}\text { organic carbon } \\
\left(\mathrm{C}_{\text {org }}\right)\end{array}$ & $\begin{array}{l}\text { fulvic acid } \\
\text { (FA) }\end{array}$ & $\begin{array}{l}\text { humic acid } \\
\text { (HA) }\end{array}$ \\
\hline \multirow{2}{*}{ Green waste } & 2015 & $19.5 \pm 0.44$ & $10.1 \pm 0.21$ & $1.10 \pm 0.03$ & $5.30 \pm 0.21$ \\
\hline & 2016 & $20.1 \pm 0.25$ & $11.3 \pm 3.50$ & $0.53 \pm 0.00$ & $1.70 \pm 0.16$ \\
\hline \multirow{2}{*}{ Food waste } & 2015 & $42.4 \pm 0.62$ & $27.6 \pm 0.14$ & $1.39 \pm 0.10$ & $6.10 \pm 0.16$ \\
\hline & 2016 & $43.6 \pm 0.40$ & $23.1 \pm 0.10$ & $2.20 \pm 0.13$ & $9.50 \pm 1.10$ \\
\hline \multirow{2}{*}{ Sewage sludge } & 2015 & $42.7 \pm 0.62$ & $22.7 \pm 0.16$ & $1.40 \pm 0.21$ & $6.90 \pm 0.51$ \\
\hline & 2016 & $36.8 \pm 0.12$ & $20.6 \pm 0.14$ & $0.46 \pm 0.06$ & $0.76 \pm 0.08$ \\
\hline \multirow{2}{*}{ Cattle manure } & 2015 & $63.1 \pm 0.64$ & $32.5 \pm 0.33$ & $0.57 \pm 0.01$ & $11.7 \pm 0.30$ \\
\hline & 2016 & $60.5 \pm 2.70$ & $22.9 \pm 0.42$ & $1.10 \pm 0.18$ & $12.7 \pm 2.60$ \\
\hline \multirow{2}{*}{$\begin{array}{l}\text { Digestate (biogas } \\
\text { production residue) }\end{array}$} & 2015 & $91.4 \pm 0.49$ & $45.9 \pm 0.24$ & $0.10 \pm 0.03$ & $0.26 \pm 0.21$ \\
\hline & 2016 & $92.5 \pm 0.15$ & $36.1 \pm 2.20$ & $0.78 \pm 0.07$ & $1.20 \pm 0.07$ \\
\hline
\end{tabular}

Green waste compost was less rich in organic matter of all composts analysed; however, the compost produced in 2015 demonstrated a substantial content of FA and HA (1.1\% and 5.3\%, respectively), and in 2016 the content of these acids was significantly lower. This can be explained by the fact that every year compost composition varies substantially, the amount of certain biodegradable substances may change. Green waste and sewage sludge composts were known as a potential source of pollution (Watteau, Villemin, 2011). Food waste and sewage sludge composts exhibited similar content of organic matter and $\mathrm{C}_{\text {org }}$ (Zbytniewski, Buszewski, 2005). The content of FA and HA in food waste in 2015 and 2016 increased as follows: FA - by $1.4-2.2 \%$, HA - by $6.1-9.5 \%$. On the contrary, the comparison of these two years in terms of the content of these acids in sewage sludge compost demonstrated a substantial decrease: FA - by $1.4-0.46 \%$, HA - by $6.9-0.76 \%$. Manure compost was rich in organic matter: $63.1 \%$ in 2015 and $60.5 \%$ in 2016. A substantial amount of $\mathrm{C}_{\text {org }}$ was found in it, and it also demonstrated the largest content of FA. The content of HA depends on compost ingredients which must be properly balanced (Alsanius et al., 2016). The maximum content of organic matter and $\mathrm{C}_{\text {org }}$ was observed in digestate compost; however, the content of FA and HA vital for plant growth was minimal. It can be explained by the fact that the digestion process occurred in anaerobic conditions, thus because of the lack of oxygen only small part if any at all of complex FA and HA was formed (Möller, Müller, 2012).
To assess the nutritional quality of composts: $\mathrm{N}, \mathrm{P}, \mathrm{K}$, their water soluble forms, $\mathrm{S}$, and carbon and nitrogen ratio $(\mathrm{C}: \mathrm{N})$, were established. The results are presented in Table 2. As mentioned earlier, not only carbon is important for soil and plants but also N, P and $\mathrm{K}$ are the basic substances needed for microorganism activity in composting. These elements are the key in assessing compost quality. The total $\mathrm{N}, \mathrm{P}$ and $\mathrm{K}$ contents indicate their total amount in compost, and water soluble forms - how much of them plants can assimilate. The total contents of these substances are usually much higher compared to water soluble ones. The $\mathrm{C}: \mathrm{N}$ ratio is important for the composting process. Microorganisms absorb carbon for energy generation and growth, while $\mathrm{N}$ is the most important substance in protein synthesis and reproduction (Staugaitis et al., 2011).

Of all the composts analysed green waste compost demonstrated the minimum contents of total $\mathrm{N}-0.65-0.69 \%$, total $\mathrm{P}-0.17-0.42 \%$ and the water soluble $\mathrm{N}-\mathrm{NH}_{4}-<0.05-38 \mathrm{mg} \mathrm{kg}^{-1}$. The total $\mathrm{N}$ content in food waste, sewage sludge, cattle manure and digestate waste was very similar in 2015 and 2016 and ranged from $2.2 \%$ to $3.3 \%$ (statistically not significant at $p \leq 0.05$ ). The scientists from other countries investigated manure and sewage sludge composts and discovered similar total $\mathrm{N}$ contents, namely $2.7 \%$ and $2.8 \%$ (Chang Chien et al., 2007; Tontti et al., 2008). However, the highest plant available $\mathrm{N}_{-} \mathrm{NH}_{4}$ content was found in digestate compost: $1409 \mathrm{mg} \mathrm{kg}^{-1}$ in 2015 and $1420 \mathrm{mg} \mathrm{kg}^{-1}$ in 2016. The digestate $\mathrm{N}^{-\mathrm{NH}_{4}}$ content is directly related to the 
Table 2. Nutrient contents (expressed in dry matter) in different types of compost

\begin{tabular}{|c|c|c|c|c|c|c|c|c|c|}
\hline \multirow[b]{2}{*}{ Composts } & \multirow[b]{2}{*}{ Year } & \multicolumn{7}{|c|}{ Nutrients } & \multirow[b]{2}{*}{$\mathrm{C}: \mathrm{N}$} \\
\hline & & $\begin{array}{l}\text { total } \\
\text { nitrogen } \\
(\mathrm{N}) \\
\%\end{array}$ & $\begin{array}{c}\text { water soluble } \\
\text { nitrogen } \\
\left(\mathrm{N}-\mathrm{NH}_{4}\right) \\
\mathrm{mg} \mathrm{kg}^{-1}\end{array}$ & $\begin{array}{c}\text { total } \\
\text { phosphorus } \\
\text { (P) } \\
\%\end{array}$ & $\begin{array}{l}\text { water soluble } \\
\text { phosphorus } \\
(\mathrm{P}) \\
\mathrm{mg} \mathrm{kg}^{-1}\end{array}$ & $\begin{array}{l}\text { total } \\
\text { potassium } \\
(\mathrm{K}) \\
\%\end{array}$ & $\begin{array}{l}\text { water soluble } \\
\text { potassium } \\
(\mathrm{K}) \\
\mathrm{mg} \mathrm{kg}^{-1}\end{array}$ & $\begin{array}{l}\text { total } \\
\text { sulphur } \\
\text { (S) } \\
\%\end{array}$ & \\
\hline \multirow{2}{*}{ Green waste } & 2015 & $0.65 \mathrm{a}$ & $38.0 \mathrm{a}$ & $0.42 \mathrm{ab}$ & $43.7 \mathrm{a}$ & $1.0 \mathrm{~b}$ & $509 \mathrm{a}$ & $0.23 \mathrm{c}$ & $15.6 \mathrm{cde}$ \\
\hline & 2016 & $0.69 \mathrm{a}$ & $<0.05$ & $0.17 \mathrm{a}$ & $39.8 \mathrm{a}$ & $0.46 \mathrm{ab}$ & $988 \mathrm{~b}$ & $0.14 \mathrm{~b}$ & $16.4 \mathrm{e}$ \\
\hline \multirow{2}{*}{ Food waste } & 2015 & $2.6 \mathrm{bc}$ & $867 \mathrm{f}$ & $0.66 \mathrm{bc}$ & $89.4 \mathrm{a}$ & $1.1 \mathrm{~b}$ & $2898 \mathrm{c}$ & $0.25 \mathrm{c}$ & $10.6 \mathrm{f}$ \\
\hline & 2016 & $2.4 \mathrm{bc}$ & $420 \mathrm{e}$ & $0.52 \mathrm{bc}$ & $35.2 \mathrm{a}$ & $0.64 \mathrm{ab}$ & $4594 \mathrm{f}$ & $0.35 \mathrm{~d}$ & $9.7 \mathrm{~b}$ \\
\hline \multirow{2}{*}{ Sewage sludge } & 2015 & 2.9 cde & $1217 \mathrm{~g}$ & $2.0 \mathrm{~g}$ & $81.2 \mathrm{a}$ & $0.47 \mathrm{ab}$ & $671 \mathrm{a}$ & $0.63 \mathrm{f}$ & $7.9 \mathrm{a}$ \\
\hline & 2016 & $2.2 \mathrm{~b}$ & $311 \mathrm{~b}$ & 1.4 ef & $67.5 \mathrm{a}$ & $0.22 \mathrm{a}$ & $1042 \mathrm{~b}$ & $0.95 \mathrm{~g}$ & $9.4 \mathrm{~b}$ \\
\hline \multirow{2}{*}{ Cattle manure } & 2015 & 2.8 cde & $316 \mathrm{~b}$ & $0.83 \mathrm{~cd}$ & $203 \mathrm{~b}$ & $4.7 \mathrm{~d}$ & $5949 \mathrm{~g}$ & $0.34 \mathrm{~d}$ & $11.6 \mathrm{~g}$ \\
\hline & 2016 & $2.4 \mathrm{bc}$ & $<0.05$ & $1.5 \mathrm{ef}$ & $288 \mathrm{c}$ & $2.2 \mathrm{c}$ & $3475 \mathrm{~d}$ & $0.38 \mathrm{e}$ & $9.5 \mathrm{~b}$ \\
\hline \multirow{2}{*}{$\begin{array}{l}\text { Digestate (biogas } \\
\text { production residue) }\end{array}$} & 2015 & $3.3 \mathrm{e}$ & $1409 \mathrm{~d}$ & $1.6 \mathrm{f}$ & $1047 \mathrm{e}$ & $0.79 \mathrm{ab}$ & $1122 \mathrm{~b}$ & $0.09 \mathrm{a}$ & $13.8 \mathrm{~h}$ \\
\hline & 2016 & $2.4 \mathrm{bc}$ & $1420 \mathrm{~d}$ & $1.2 \mathrm{de}$ & $370 \mathrm{~d}$ & $0.34 \mathrm{ab}$ & $3887 \mathrm{e}$ & $0.13 \mathrm{~b}$ & $15.4 \mathrm{c}$ \\
\hline
\end{tabular}

Note. The difference between the values with the same letter was not statistically significant between the different composts at $p \leq 0.05$ according to Duncan's test.

original feedstock total N content (Möller, Müller, 2012). Asubstantial content was also observed in sewage sludge compost - in 2015 it totalled $1217 \mathrm{mg} \mathrm{kg}^{-1}$. The maximum total $\mathrm{P}$ content was found in sewage sludge compost and the minimum one was observed in green waste compost. However, the highest content of water-soluble $\mathrm{P}$ was established in manure compost - 203-288 mg kg-1. In 2015 , it was established that the total $\mathrm{K}$ in green waste, food waste, sewage sludge and digestate composts was similar and ranged from $0.46 \%$ to $1.05 \%$. In 2016 , the same composts demonstrated the significantly lower content of total $\mathrm{K}-0.22-0.64 \%$ (statistically significant differences were obtained between years at $p \leq 0.05$ ). The maximum contents of total $\mathrm{K}$ were found in manure compost: $4.7 \%$ in 2015 and $2.2 \%$ in 2016 . The content of water soluble $\mathrm{K}$ in 2016 was significantly higher despite the fact that in 2015 total $\mathrm{K}$ contents were twice as high. The maximum total S contents were determined in sewage sludge compost: $0.63 \%$ in 2015 and $0.95 \%$ in 2016 , and the minimum content was recorded in biogas production residue compost $-0.09-0.13 \%$. Green waste compost exhibited the largest $\mathrm{C}: \mathrm{N}$. Our results agree with those of other scientists who investigated composts of similar composition (Alsanius et al., 2016; Staugaitis et al., 2016).

The difference between the amount of obtained nutrients in 2015 and 2016 composts (Table 2) could be explained by the weather conditions. Figure 1 shows the weather conditions during the composting period. In November and December 2014, the temperature was a little higher which means that conditions for organic matter decomposition were better. High amount of rainfall in November 2015 and February 2016 affected K and N content (Table 2). The lower amount of $\mathrm{K}$ and $\mathrm{N}$ content could be due to nutrient leaching in 2016 compost samples (Tiquia et al., 2002).

Table 3 shows the contents of heavy metals in green waste, food waste, sewage sludge, cattle manure and digestate composts. In this study there were determined seven major heavy metals: cadmium $(\mathrm{Cd})$, lead $(\mathrm{Pb})$, nickel $(\mathrm{Ni})$, copper $(\mathrm{Cu})$, zinc $(\mathrm{Zn})$, chromium $(\mathrm{Cr})$ and mercury $(\mathrm{Hg})$.

Table 3. Heavy metal contents (expressed in $\mathrm{mg} \mathrm{kg}^{-1}$ of dry matter) in different types of compost

\begin{tabular}{lcccccccc}
\hline \multirow{2}{*}{\begin{tabular}{c} 
Composts \\
\cline { 3 - 9 }
\end{tabular}} & Year & \multicolumn{7}{c}{ Heavy metals } \\
\cline { 3 - 9 } Green waste & 2015 & $0.32 \pm 0.01$ & $40.7 \pm 10.2$ & $7.7 \pm 1.2$ & $74 \pm 3.2$ & $492 \pm 66$ & $12.7 \pm 1.7$ & $0.64 \pm 0.05$ \\
& 2016 & $0.18 \pm 0.01$ & $12.7 \pm 0.78$ & $5.1 \pm 0.11$ & $15.7 \pm 1.1$ & $145 \pm 16$ & $15.7 \pm 4.0$ & $0.01 \pm 0.00$ \\
\hline \multirow{2}{*}{ Food waste } & 2015 & $0.11 \pm 0.02$ & $8.3 \pm 1.8$ & $4.2 \pm 1.2$ & $15.6 \pm 2.5$ & $85 \pm 3.5$ & $7.3 \pm 1.1$ & $0.00 \pm 0.00$ \\
& 2016 & $0.12 \pm 0.00$ & $7.1 \pm 0.71$ & $3.5 \pm 0.71$ & $19.0 \pm 1.1$ & $108 \pm 19$ & $4.97 \pm 0.9$ & $0.019 \pm 0.00$ \\
\hline \multirow{2}{*}{ Sewage sludge } & 2015 & $2.0 \pm 0.27$ & $61.0 \pm 8.5$ & $42.2 \pm 3.1$ & $198 \pm 18$ & $1059 \pm 86$ & $78.7 \pm 2.0$ & $0.60 \pm 0.00$ \\
& 2016 & $2.1 \pm 0.07$ & $41.2 \pm 0.21$ & $36.8 \pm 0.49$ & $200 \pm 7.8$ & $1191 \pm 30$ & $45.8 \pm 0.99$ & $0.04 \pm 0.01$ \\
\hline \multirow{2}{*}{ Cattle manure } & 2015 & $0.17 \pm 0.00$ & $<2.5^{*}$ & $2.6 \pm 0.37$ & $29.8 \pm 2.1$ & $158 \pm 10$ & $3.1 \pm 0.10$ & $0.00 \pm 0.00$ \\
& 2016 & $0.22 \pm 0.01$ & $3.2 \pm 0.40$ & $3.7 \pm 0.66$ & $29.4 \pm 1.6$ & $126 \pm 6.4$ & $6.1 \pm 1.1$ & $0.01 \pm 0.00$ \\
\hline Digestate (biogas & 2015 & $0.20 \pm 0.07$ & $<2.5^{*}$ & $6.7 \pm 0.66$ & $26.1 \pm 1.4$ & $333 \pm 32$ & $5.6 \pm 0.57$ & $0.00 \pm 0.00$ \\
production residue) & 2016 & $0.21 \pm 0.01$ & $<2.5^{*}$ & $4.3 \pm 0.02$ & $12.6 \pm 0.07$ & $226 \pm 4.9$ & $1.9 \pm 0.19$ & $0.07 \pm 0.01$ \\
\hline
\end{tabular}

* - detection limit

Heavy metal contents were compared with the contents of heavy metals in the composts of different categories recommended by the Agrochemical Research Laboratory of the Lithuanian Research Centre for Agriculture and Forestry (Table 4). These contents of heavy metals were calculated on the basis of limits of heavy metals in composts submitted by 19 countries and having assessed their contents in composts produced in Lithuania (Staugaitis et al., 2015).

In terms of organic matter and nutrient contents, green waste compost was the most neutral of all composts; however, we could not state that for heavy metal contents. The largest content of heavy metals was obtained in green waste compost in 2015: $\mathrm{Cu}-74, \mathrm{Zn}-492$ and 
Table 4. Permissible limits of heavy metal contents $\left(\mathrm{mg} \mathrm{kg}^{-1}\right)$ in different categories of composts

\begin{tabular}{ccccccccc}
\hline Category & $\mathrm{Cd}$ & $\mathrm{Pb}$ & $\mathrm{Hg}$ & $\mathrm{Cr}$ & $\mathrm{Zn}$ & $\mathrm{Cu}$ & $\mathrm{Ni}$ & $\mathrm{As}$ \\
\hline I & $\leq 0.7$ & $\leq 45$ & $\leq 0.4$ & $\leq 70$ & $\leq 200$ & $\leq 70$ & $\leq 25$ & $\leq 10$ \\
II & $\leq 1.3$ & $\leq 130$ & $\leq 1.0$ & $\leq 100$ & $\leq 400$ & $\leq 110$ & $\leq 40$ & $\leq 15$ \\
III & $\leq 3.0$ & $\leq 180$ & $\leq 2.0$ & $\leq 120$ & $\leq 600$ & $\leq 300$ & $\leq 60$ & $\leq 25$ \\
\hline
\end{tabular}

I - use in agriculture, II - use for energy crops, III - for non-agricultural land use, rehabilitated areas

$\mathrm{Hg}-0.64 \mathrm{mg} \mathrm{kg}{ }^{-1}$. In accordance with the following exceeded limits of heavy metals (Table 4), green waste compost was classified as category III. The green waste compost produced in 2016 was of a much better quality and was classified as category I. Food waste and cattle manure composts met the highest standards and were classified as category I. The maximum contamination by heavy metals was observed in sewage sludge compost: $\mathrm{Cd}-2.0-2.1, \mathrm{~Pb}-41.2-61.0, \mathrm{Ni}-36.8-42.2, \mathrm{Cu}-$ 198-200, Zn - 1059-1191 and $\mathrm{Cr}-78.7-45.8 \mathrm{mg} \mathrm{kg}^{-1}$. Similar results have been obtained by other researchers (Watteau, Villemin, 2011; Singh et al., 2016). Zn content in sewage sludge compost significantly (1.8-2.0 times) exceeded the heavy metal limits set out for category III; therefore, it could not be attributed to either category. Digestate compost was classified as category II, as the $\mathrm{Zn}$ content exceeded the limits set out for category I.

Polychlorinated biphenyls (PCBs) belong to the 12 most harmful persistent organic pollutants, as specified in Stockholm convention (Antolín-Rodríguez et al., 2016). There are altogether 209 different PCBs, and about 130 of them were used in commercial products. Due to their bio-accumulating properties, these compounds build up in the food chain with exposure of animals, possibly impacting biodiversity and ultimately humans, causing health impacts for current and future generations (Weber et al., 2011). However, only some from 209 PCBs congeners are usually selected for monitoring (Vorkamp, 2016). During this research work, the total contents of PCB 28, PCB 52, PCB 101, PCB 118, PCB 153, PCB 180 and $\mathrm{PCB} 138+163$ were determined. The results obtained are shown in Figure 2.

Chromatographic separation involved problems separating PCB 138 from PCB 163; therefore, the study assessed the sum of these two compounds. It was found

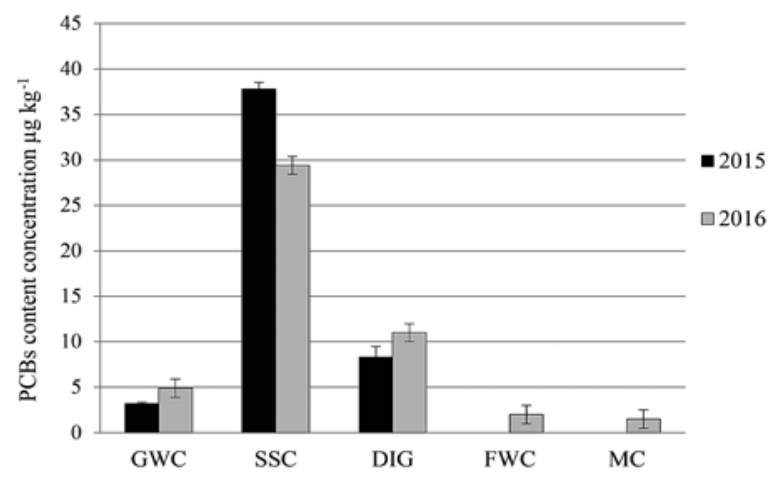

GWC - green waste compost, SSC - sewage sludge compost, DIG - digestate (biogas production residue), FWC - food waste compost, $\mathrm{MC}$ - manure compost

Figure 2. Total amount of 7 polychlorinated biphenyls (PCBs) content in different types of compost that sewage sludge compost were the most contaminated with PCBs, containing the overall content of $37.8 \mu \mathrm{g} \mathrm{kg}^{-1}$ in the samples of 2015 and $29.4 \mu \mathrm{g} \mathrm{kg}^{-1}$ in the samples from 2016. The lowest PCBs contamination was determined in cattle manure and food waste composts: there were no PCBs found in the samples of 2015, and the PCBs contents in the samples of 2016 were 1.5 and $2.0 \mu \mathrm{g} \mathrm{kg}^{-1}$, respectively. There are no legal acts governing the contamination of composts as soil improvement materials with persistent organic pollutants in Lithuania. In accordance with the hygienic norm $\mathrm{HN}$ 60:2004 (https://e-seimas.lrs.lt/portal/legalAct/lt/TAD/ TAIS.228693) which describes the maximum permissible concentrations of hazardous chemical substances in the soil, $0.1 \mathrm{mg} \mathrm{kg}^{1}$ of PCBs can be permitted. According to the quality requirements for composts used in agriculture (Staugaitis et al., 2011), it is recommended that the total content of polychlorinated biphenyls does not exceed $400 \mu \mathrm{g} \mathrm{kg}^{-1}$ in dry matter. All investigated composts satisfied this requirement. Polychlorinated biphenyls might have 1 to 10 chlorine atoms. The more chlorine atoms a molecule has, the more complex is its degradation process. Another important characteristic determining PCBs degradation is the placement of a chlorine atom in the molecule (Anyasi, Atagana, 2011). The obtained results correlate with the data of other authors, who investigated green waste compost, household biowaste compost and digestate compost obtained under anaerobic conditions (Brändli et al., 2008; Riedel, Marb, 2008). Swiss researchers Berset and Holzer (1995) established on average $32 \mu \mathrm{g} \mathrm{kg}^{-1}$ of PCBs in compost. A higher content of about $400 \mu \mathrm{g} \mathrm{kg}^{-1}$ was found in sewage sludge (Berset, Holzer, 1995). The most predominant PCB detected was PCB 28 (2,4,4'-trichlorobiphenyl), which has three chlorine atoms in its molecule. Its content ranged from $0.14 \mu \mathrm{g} \mathrm{kg}^{-1}$ in the sewage sludge compost sample of 2015 up to $3.24 \mu \mathrm{g} \mathrm{kg}^{-1}$ in the biogas production residue sample of 2016. Having five chlorine atoms PCB 118 (2,3',4,4',5-pentachlorbiphenyl) was found only in sewage sludge compost. Its content in the sample of 2015 was $18.91 \mu \mathrm{g} \mathrm{kg}^{-1}-$ it is the least common compound of all PCBs analysed.

Sixteen different polycyclic aromatic hydrocarbons with two to six benzene rings were determined. The most common are PAHs with five or six benzene rings. PAHs with less than six benzene rings are defined as the small PAHs and those with more than six benzene rings in their structure are defined as the large PAHs (Moss, 1998). Five composts of different origin were examined in which the content of polycyclic aromatic hydrocarbons was established (Fig. 3). PAHs are characterised by their carcinogenic, mutagenic and toxic impact on the environmental (Fetzer, 2007). 

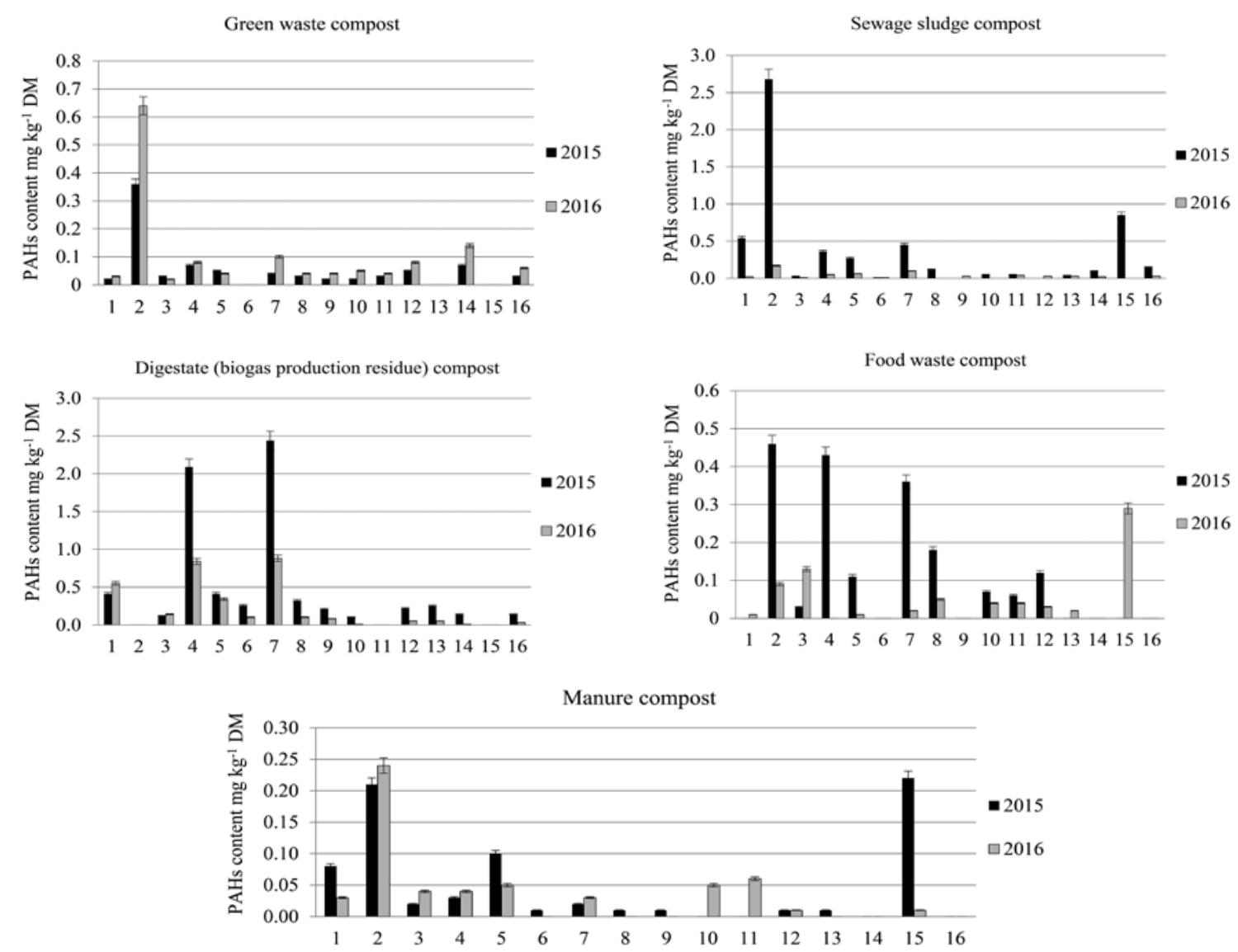

Note. 1 - naphthalene, 2 - acenaphthylene, 3 - acenaphthene, 4 - fluorine, 5 - phenanthrene, 6 - anthracene, 7 - fluoranthene, 8 - pyrene, 9 - benz[a]anthracene, 10 - chrysene, 11 - benzo[b]fluoranthene, 12 - benzo[k]fluoranthene, 13 - benzo[a]pyrene, 14 - benzo[g,hi,]perylene, 15 - dibenz[a,h]anthracene, 16 - indeno[1,2,3-cd]pyrene; if there is no value in the graph that means that compound was not detected.

Figure 3. Polycyclic aromatic hydrocarbons (PAHs) content in different types of compost

According to the quality requirements for composts used in agriculture (Staugaitis et al., 2011), it is recommended that the total content of PAHs should not exceed $4 \mathrm{mg} \mathrm{kg}^{-1}$ in dry matter. Of all investigated composts the recommended total of 16 PAHs was higher only in SSC and digestate of 2015 and it amounted to 5.70 and $7.11 \mathrm{mg} \mathrm{kg}^{-1}$, respectively (Fig. 4). An explanation for this finding may be different contamination levels and different origin of the input material. None of the compost samples of 2016 demonstrated PAHs contents higher than $4 \mathrm{mg} \mathrm{kg}^{-1}$. All samples analysed had different concentrations of individual PAHs. The most common compounds were acenaphthylene, fluorene, phenanthrene and dibenz(a,h)anthracene.

Our data agree with those published by other authors, who analysed green waste compost, household biowaste compost and digestate compost produced by anaerobic treatment, and the average PAHs contents determined by them were $1.23,2.31$ and $2.68 \mathrm{mg} \mathrm{kg}^{-1}$, respectively (Moeller, Reeh, 2003; Riedel, Marb, 2008). There are also literature sources that report higher PAHs contents found in composts (Brändli et al., 2006). While carrying out the studies in different seasons (summer and winter), it was found that the ambient temperature was related to pollution of composts with PAHs (Stäb et al., 2008). Higher concentrations of polycyclic aromatic

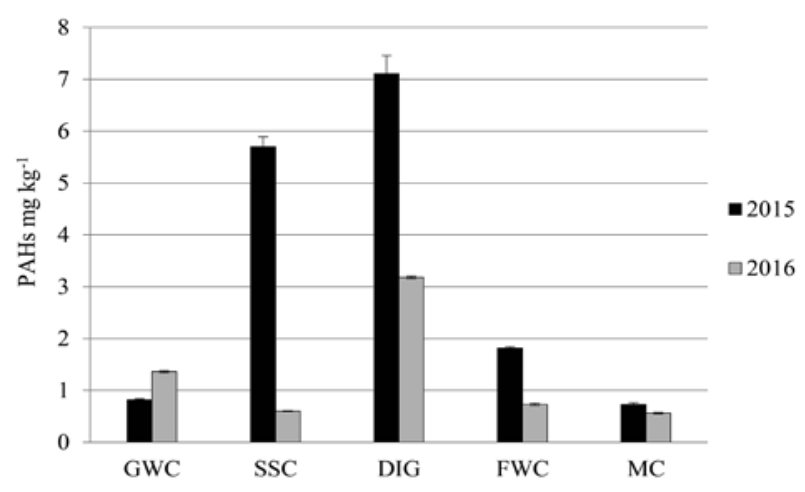

GWC - green waste compost, SSC - sewage sludge compost, $\mathrm{DIG}$ - digestate (biogas production residue), $\mathrm{FWC}$ - food waste compost, $\mathrm{MC}$ - manure compost

Figure 4. Total amount of 16 polycyclic aromatic hydrocarbons (PAHs) content in different types of compost

hydrocarbons in the samples of winter compost can be explained by the use of fossil fuel during the heating season which determined higher concentrations of PAHs in compost. In this study, compost samples were taken in spring, according to results obtained by Stäb et al. (2008), composts made from feedstock materials colected during summer season were less contaminated PAHs. 


\section{Conclusions}

1. The analysis of organic matter content in different types of composts revealed that the maximum contents of organic matter and organic carbon $\left(\mathrm{C}_{\text {org }}\right)$ were demonstrated by digestate (biogas production residue) compost; however, the contents of fulvic (FA) and humic (HA) acids were minimal. The maximum contents of FA and HA were determined in cattle manure compost. The lowest content of organic matter was determined in green waste compost.

2. The composts produced from food waste, sewage sludge, cattle manure and digestate had similar contents of total nitrogen $(\mathrm{N})$; however, plant available water soluble ammonia nitrogen content was the highest in digestate. Sewage sludge compost demonstrated the highest contents of total phosphorus (P) and total sulphur (S). The maximum content of total and water soluble potassium $(\mathrm{K})$ was observed in cattle manure compost.

3. Having analysed five composts of different origin it was established that none of them exceeded the limits for polychlorinated biphenyls (PCBs) recommended for composts used in agriculture. However, the most polluted by heavy metals and PCBs was sewage sludge compost. Food waste and cattle manure composts revealed the minimum contents of heavy metals and PCBs.

4. The research data suggest that pollution with polycyclic aromatic hydrocarbons (PAHs) decreased in two year period. The highest decrease (9.5 times) in PAHs concentration was recorded in sewage sludge compost. The PAHs contents in the samples of digestate and food waste compost of 2016 were about 2.5 times lower. The only exception was the green waste compost, in which 1.6 times higher PAHs content was found in 2016. Higher contents of PAHs in 2016 year samples were found due to the more contaminated input materials used for composting.

Received 14022018 Accepted 08062018

\section{References}

1. Alsanius B. W., Blok C., Cuijpers W. J. M., Franca S. C., Fuchs J. G., Janmaat L., Raviv M., Streminska M. A., Termorshuizen A. J. 2016. Handbook for composting and compost use in organic horticulture. Research Report. BioGreenhouse COST Action FA 1105, p. 18-22.

2. Antolín-Rodríguez J. M., Sánchez-Báscones M., Martín-Ramos P., Bravo-Sánchez C. T., Martín-Gil J. 2016. Estimation of PCB content in agricultural soils associated with long-term fertilization with organic waste. Environmental Science and Pollution Research, 23 (12): 12372-12383.

https://doi.org/10.1007/s11356-016-6439-1

3. Anyasi R. O., Atagana H. I. 2011. Biological remediation of polychlorinated biphenyls (PCB) in the environment by microorganisms and plants. African Journal of Biotechnology, 10: 18916-18938. https://doi.org/10.5897/AJB10.557

4. Banach-Szott M., Debska B., Rosa E. 2014. Effect of soil pollution with polycyclic aromatic hydrocarbons on the properties of humic acids. Journal of Soils and Sediments, 14 (6): 1169-1178.

https://doi.org/10.1007/s11368-014-0873-9
5. Bedada W., Karltun E., Lemenih M., Tolera M. 2014. Long-term addition of compost and NP fertilizer increases crop yield and improves soil quality in experiments on smallholder farms. Agriculture, Ecosystems and Environment, 195: 193-201.

https://doi.org/10.1016/j.agee.2014.06.017

6. Berset J., Holzer R. 1995. Organic micropollutants in Swiss agriculture: distribution of polynuclear aromatic hydrocarbons (PAH) and polychlorinated biphenyls (PCB) in soil, liquid manure, sewage sludge and compost samples; a comparative study. International Journal of Environmental Analytical Chemistry, 59 (2-4):145-165. https://doi.org/10.1080/03067319508041324

7. Brändli R. C., Bucheli T. D., Kupper T., Zennegg M., Berger U., Edder P., Oehme M., Müller J., Schaffner C., Furrer R., Schmid P., Huber S., Ortelli D., Iozza S., Stadelmann F. X., Tarradellas J. 2006. Organic pollutants in source-separated compost. Organohalogen Compounds, 68: 863-866.

8. Brändli R. C., Bucheli T. D., Kupper T., Zennegg M., Huber S., Müller J., Schmid P., Berger U., Stahel W., Stadelmann F. X. 2008. Input of organic pollutants to soil by compost and digestate application and their origin. International congress CODIS 2008, session 2.2. Solothurn, Switzerland, p. 55-62.

9. Butkovskyi A., Ni G., Leal L. H., Rijnaarts H. H. M., Zeeman G. 2016. Mitigation of micropollutants for black water application in agriculture via composting of anaerobic sludge. Journal of Hazardous Materials, 303: 41-47. https://doi.org/10.1016/j.jhazmat.2015.10.016

10. Chang Chien S. W., Wang M. C., Huang C. C., Seshaiah K. 2007. Characterization of humic substances derived from swine manure-based compost and correlation of their characteristics with reactivities with heavy metals. Journal of Agricultural and Food Chemistry, 55 (12): 4820-4827. https://doi.org/10.1021/jf070021d

11. Debska B., Banach-Szott M., Rosa E., Drag M. 2011. Effect of soil pollution with PAHs on organic matter properties. Polish Journal of Soil Science, 44 (2): 97-103.

12. Eshetu B., Jandl G., Leinweber P. 2012. Compost changed soil organic matter molecular composition: a Py-GC/MS and Py-FIMS Study. Compost Science and Utilization, 20 (4): 230-238. https://doi.org/10.1080/1065657X.2012.10737053

13. Faithfull N. T. 2002. Methods in agricultural chemical analysis: a practical handbook. CABI Publishing, p. 68-71. https://doi.org/10.1079/9780851996080.0000

14. Fetzer J. C. 2007. The chemistry and analysis of large PAHs. Polycyclic Aromatic Compounds, 27 (2): 143-162. https://doi.org/10.1080/10406630701268255

15. Fialho L. L., Da Silva W. T. L., Milori D. M. B. P., Simões M. L., Martin-Neto L. 2010. Characterization of organic matter from composting of different residues by physicochemical and spectroscopic methods. Bioresource Technology, 101 (6): 1927-1934.

https://doi.org/10.1016/j.biortech.2009.10.039

16. Guo X., Luo L., Ma Y., Zhang S. 2010. Sorption of polycyclic aromatic hydrocarbons on particulate organic matters. Journal of Hazardous Materials, 173 (1): 130-136. https://doi.org/10.1016/j.jhazmat.2009.08.065

17. Harrison E. Z., Oakes S. R., Hysell M., Hay A. 2006. Organic chemicals in sewage sludges. Science of the Total Environment, 367 (2): 481-497.

https://doi.org/10.1016/j.scitotenv.2006.04.002

18. Hoitink H. A., Gardener B. B. M., Miller S. A 2008. Current knowledge on disease suppressive properties of composts. International congress CODIS 2008, session 1. Solothurn, Switzerland, p. 19-25. 
19. Kupper T., Brändli R. C., Bucheli T. D., Stämpfli C., Zennegg M., Berger U., Edder P., Pohl M., Niang F., Iozza S., Müller J., Schaffner C., Schmid P., Huber S., Ortelli D., Slooten K. B., Mayer J., Bachmann H. J., Stadelmann F. X., Tarradellas J. 2008. Organic pollutants in compost and digestate: occurrence, fate and impacts. International congress CODIS 2008, session 1. Solothurn, Switzerland, p. 27-34.

20. Moeller J., Reeh U. 2003. Degradation of DEHP, PAHs and LAS in source separated MSW and sewage sludge during composting. Compost Science and Utilization, 11 (4): $370-378$. https://doi.org/10.1080/1065657X.2003.10702147

21. Möller K., Müller T. 2012. Effects of anaerobic digestion on digestate nutrient availability and crop growth: a review. Engineering in Life Sciences, 12 (3): 242-257. https://doi.org/10.1002/elsc.201100085

22. Montanarella L., Rusco E. 2002. Organic matter levels in European agricultural soils. The biological treatment of biodegradable waste - technical aspects. Brussels, p. 8-10.

23. Moss G. 1998. Nomenclature of fused and bridged fused ring systems. Pure and Applied Chemistry, 70 (1): 143-216. https://doi.org/10.1351/pac199870010143

24. Paradelo R., Moldes A. B., Rodríguez M., Barral M. T. 2008. Relationship between heavy metals and phytotoxicity in composts. CYTA-Journal of Food, 6 (2): 143-151. https://doi.org/10.1080/11358120809487639

25. Pettit R. E. 2004. Organic matter, humus, humate, humic acid, fulvic acid and humin: their importance in soil fertility and plant health. CTI Research, p. 1-17.

26. Riedel H., Marb C. 2008. Heavy metals and organic contaminants in Bavarian composts - an overview. International congress CODIS 2008, session 2.2. Solothurn, Switzerland, p. 63-64.

27. Said-Pullicino D., Gigliotti G. 2007. Oxidative biodegradation of dissolved organic matter during composting. Chemosphere, 68 (6): 1030-1040. https://doi.org/10.1016/j.chemosphere.2007.02.012

28. Sánchez-García M., Alburquerque J. A., SánchezMonedero M. A., Roig A., Cayuela M. L. 2015. Biochar accelerates organic matter degradation and enhances $\mathrm{N}$ mineralisation during composting of poultry manure without a relevant impact on gas emissions. Bioresource Technology, 192: 272-279. https://doi.org/10.1016/j.biortech.2015.05.003

29. Scaglia B., Pognani M., Adani F. 2015. Evaluation of hormone-like activity of the dissolved organic matter fraction (DOM) of compost and digestate. Science of the Total Environment, 514: 314-321. https://doi.org/10.1016/j.scitotenv.2015.02.009

30. Schuchardt F. 2005. Composting of organic waste. Jördening H. J., Winter J. (eds). Environmental biotechnology: concepts and applications, p. 333-354.

31. Singh J., Kalamdhad A. S. 2013. Chemical speciation of heavy metals in compost and compost amended soil - a review. International Journal of Environmental Engineering Research, 2 (2): 27-37.

32. Singh W. R., Kalamdhad A. S., Singh J. 2016. The preferential composting of water fern and a reduction of the mobility of potential toxic elements in a rotary drum reactor. Process Safety and Environmental Protection, 102: 485-494. https://doi.org/10.1016/j.psep.2016.05.002

33. Stäb J., Kuch B., Rupp S., Fischer K., Kranert M., Metzger J. W. 2008. Determination of organic contaminants in compost and digestates in Baden-Württemberg, SouthWest Germany. International congress CODIS 2008, session 2.2. Solothurn, Switzerland, p. 73-77.
34. Staugaitis G., Mažeika R., Antanaitis A., Antanaitis Š. 2011. Komposto, naudojamo žemès ūkyje, kokybès reikalavimų analizė ir ivertinimas: taikomojo mokslinio tyrimo ataskaita. Lithuanian Research Centre for Agriculture and Forestry, p. 52-78 (in Lithuanian).

35. Staugaitis G., Mažeika R., Gvildienè K., Narutytė I. 2015. Assessment of compost materials and quality. Innovative solutions of soil and agrochemistry science. Kaunas, Lithuania, p. 256-267, 306 (in Lithuanian).

36. Staugaitis G., Narutytė I., Arbačauskas J., Vaišvila Z., Rainys K., Mažeika R., Masevičienė A., Žičkienė L., Šumskis D. 2016. The influence of composts on yield and chemical elements of winter wheat and spring barley. Zemdirbyste-Agriculture, 103 (4): 355-362. https://doi.org/10.13080/z-a.2016.103.045

37. Tiquia S., Richard T., Honeyman M. 2002. Carbon, nutrient, and mass loss during composting. Nutrient Cycling in Agroecosystems, 62 (1): 15-24.

https://oi.org/10.1023/A:1015137922816

38. Tontti T., Palojärvi A., Heinonen-Tanski H., Halinen A., Karinen P. 2008. Effects of repeated municipal waste compost fertilizations on soil and plants in a crop rotation field experiment in Finland. International congress CODIS 2008, session 3. Solothurn, Switzerland, p. 97-98.

39. Tremolada P., Guazzoni N., Smillovich L., Moia F., Comolli R. 2012. The effect of the organic matter composition on POP accumulation in soil. Water, Air and Soil Pollution, 223 (7): 4539-4556. https://doi.org/10.1007/s11270-012-1216-3

40. Vorkamp K. 2016. An overlooked environmental issue? A review of the inadvertent formation of PCB-11 and other $\mathrm{PCB}$ congeners and their occurrence in consumer products and in the environment. Science of the Total Environment, 541: $1463-1476$. https://doi.org/10.1016/j.scitotenv.2015.10.019

41. Watteau F., Villemin G. 2011. Characterization of organic matter microstructure dynamics during co-composting of sewage sludge, barks and green waste. Bioresource Technology, 102 (19): 9313-9317. https://doi.org/10.1016/j.biortech.2011.07.022

42. Weber R., Watson A., Forter M., Oliaei F. 2011. Persistent organic pollutants and landfills a review of past experiences and future challenges. Waste Management and Research, 29 (1): 107-121. https://doi.org/10.1177/0734242X10390730

43. Zbytniewski R., Buszewski B. 2005. Characterization of natural organic matter (NOM) derived from sewage sludge compost. Part 1: chemical and spectroscopic properties. Bioresource Technology, 96 (4): 471-478. https://doi.org/10.1016/j.biortech.2004.05.018 
ISSN 1392-3196 / e-ISSN 2335-8947

Zemdirbyste-Agriculture, vol. 105, No. 3 (2018), p. 211-220

DOI 10.13080/z-a.2018.105.027

\title{
İvairių rūšių kompostų taršos lygio įvertinimas ir tinkamumas žemès ūkiui
}

\author{
I. Višniauskè', K. Barčauskaitè2, E. Bakšienè $\dot{e}^{3}$, R. Mažeika² \\ ${ }^{1}$ Lietuvos agrarinių ir miškų mokslų centro Agrocheminių tyrimų laboratorija \\ ${ }^{2}$ Lietuvos agrarinių ir miškų mokslų centro Žemdirbystès institutas \\ ${ }^{3}$ Lietuvos agrarinių ir miškų mokslų centro Vokès filialas
}

\section{Santrauka}

Tyrimo tikslas - ištirti žaliụjų bei maisto atliekų, nuotekų dumblo, galvijų méšlo ir biodujų gamybos atliekų kompostų organinès medžiagos sudètị ir ịvertinti jų užterštumą patvariais organiniais teršalais bei sunkiaisiais metalais. Tirti 2015 ir 2016 m. pagaminti kompostai, paimti iš įvairių Lietuvos regionų, įvertinus nevienodas oro sąlygas. Kompostų cheminè analizė buvo atlikta pagal tarptautinius standartus ir reikalavimus dirvožemio gerinimo medžiagoms. Iš visų tirtų kompostų mažiausi kiekiai organinès medžiagos, azoto, fosforo buvo nustatyti žaliųjų atliekų komposte. Biodujų gamybos atliekų kompostas, nors ir pasižymėjo didžiausiu organinès medžiagos kiekiu, tačiau turèjo mažiausiai fulvinių ir huminių rūgščių, kurios yra svarbios dirvožemio organinès dalies atkūrimui. Nustatyta, kad sunkiaisiais metalais ir polichlorbifenilais labiausiai užteršti yra nuotekų dumblo kompostai, kuriuose bendras tirtų polichlorbifenilų kiekis $2015 \mathrm{~m}$. siekè $37,8 \mu \mathrm{g} \mathrm{kg}^{-1}, 2016 \mathrm{~m} .-29,4 \mu \mathrm{g} \mathrm{kg}^{-1}$. Mažiausia sunkiujų metalų ir polichlorbifenilų tarša pasižymėjo galvijų mëšlo ir maisto atliekų kompostai - $2015 \mathrm{~m}$. èminiuose polichlorbifenilų nebuvo nustatyta. Iš tirtų kompostų rekomenduojamas bendras 16 policiklinių aromatinių angliavandenilių kiekis buvo didesnis tik 2015 m. nuotekų dumblo ir biodujų gamybos atliekų kompostuose. Žemès ūkyje mažiausiai tinkamas naudoti yra nuotekų dumblo kompostas, nes tarša sunkiaisiais metalais ir patvariais organiniais teršalais gali reikšmingai padidinti teršalų koncentraciją dirvožemyje. Dirvožemyje organinès medžiagos kiekị didino tik žaliujų atliekų kompostas. Galvijų méšlo, maisto atliekų bei biodujų gamybos atliekų kompostai ne tik gerino dirvožemio struktūrą, bet ir reikšmingai didino maisto medžiagų koncentraciją.

Reikšminiai žodžiai: fulvinès rūgštys, huminès rūgštys, organinė medžiaga, polichlorbifenilai, policikliniai aromatiniai angliavandeniliai. 